\title{
Palaeoecology and palaeoenvironment of the Aquitanian locality Ulm-Westtangente (MN2, Lower Freshwater Molasse, Germany)
}

\author{
Loïc Costeur, Olivier Maridet, Stéphane Peigné, Elmar P. J. Heizmann
}

\begin{abstract}
The mammalian fauna of the German locality Ulm-Westtangente from the Aquitanian Lower Freshwater Molasse is investigated. The fauna is compared to other rich European localities of the same time period. It is shown to be one of the richest localities for fossil mammals and brings interesting insights into the composition of the Aquitanian European faunas. Sixty-one species are identified and high affinities with the French central region are confirmed. Body mass distributions of insectivores,
\end{abstract}

L. Costeur (corr.)

Naturhistorisches Museum Basel,

Augustinergasse 2, 4001 Basel, Switzerland

e-mail: loic.costeur@bs.ch

\section{O. Maridet}

Key Laboratory of Evolutionary Systematics of Vertebrates, Institute of Vertebrate Paleontology and Paleoanthropology, Chinese Academy of Sciences, PO Box 643, 100044 Beijing, China

e-mail: olivier.maridet@ivpp.ac.cn

\section{S. Peigné}

Muséum National d'Histoire Naturelle,

UMR 7207 CNRS/MNHN/UPMC,

Centre de Recherche sur la Paléobiodiversité et les

Paléoenvironnements, 8 rue Buffon, CP 38,

75005 Paris, France

e-mail: peigne@mnhn.fr

\section{E. P. J. Heizmann}

Staatliches Museum für Naturkunde Stuttgart,

Rosenstein 1, 70191 Stuttgart, Germany

e-mail: elmar.heizmann@smns-bw.de herbivores, omnivores and carnivores are analysed. Altogether, they showed that the environment at Ulm-Westtangente was probably a warm-temperate forest with grassland habitats, although temperature was still difficult to assess. Ulm-Westtangente lies between the Late Oligocene warm-temperate to subtropical conditions prevailing in Europe and the late Early to Middle Miocene very warm subtropical to tropical conditions of the Miocene Climatic Optimum. It thus represents an intermediate stage in the overall climatic evolution of the late Palaeogene-early Neogene of Europe. The comparison of its body mass distribution with a dataset of extant faunas indicates affinities with community structures found in nowadays temperate forests. However, the record of certain types of ectothermic vertebrates at Ulm-Westtangente precludes the presence of a typical temperate climate. The range of carnivore body masses is similar to what is known in extant communities, with species distributed in a restricted size range (small to middle sizes) in comparison to the insectivore/herbivore/omnivore species.

Keywords Early Miocene, Body mass, Terrestrial environments, Palaeoclimate, Mammalian palaeocommunity

\section{Introduction}

The European Aquitanian continental environments were comparatively less studied than other periods of the Late Palaeogene and Neogene because of the scarcity of data or because of the larger interest drawn by the next period. The Middle Miocene is indeed known to have experienced one of the highest climatic optimum of the Cenozoic (Böhme 2003, 2004; Böhme et al. 2011; 
Jiménez-Moreno and Suc 2007; Costeur and Legendre 2008a). The Aquitanian is an interesting period framed by the Late Oligocene global warming (Zachos et al. 2001; Dallai and Burgess 2011) and the late Early/early Middle Miocene climatic optimum (Zachos et al. 2001; Böhme 2004). Europe seemed to be marked by a period of climatic stability associated with few faunal changes, many genera being inherited from the Late Oligocene and constantly present throughout the Aquitanian (Maridet et al. 2007; Costeur and Legendre 2008b; Maridet and Costeur 2010). The whole fauna is progressively replaced by immigrant species from other continental domains (Mein 1999). The European continent showed a more fractured shape than today; western Europe was continental with a partially open Rhine Graben separating the western part from the rest of the continent to the east. This geographic configuration did not, however, yield particularly high levels of regional endemism for mammals (Maridet et al. 2007; Costeur 2009). This led credence to the hypothesis that the Aquitanian relative climatic stability and homogeneity allowed species to settle down in several regions without creating strong faunal heterogeneities. An exception to this would be the slightly more isolated Iberian Peninsula resulting in some faunal differences with the other regions (Costeur et al. 2004). However, if the relative stability and homogeneity of the European Aquitanian climate seems likely, the type of climate and associated environments prevailing remain poorly understood.

We present here a palaeoenvironmental analysis of the rich mammalian Aquitanian fauna of Ulm-Westtangente in the Lower Freshwater Molasse sediments of the BadenWürttemberg Basin in southwestern Germany. This fauna was discovered about 20 years ago and yielded a rich assemblage with more than 60 species of mammals, most of them being now described (e.g. Heizmann et al. 1989; Hellmund 1991; Ziegler 1989, 1990a, b; Werner 1994; Stefen 1997; Peigné and Heizmann 2003; Costeur and Heizmann in progress). We analyse this fauna with the cenogram method (i.e. body mass distribution of the species comprising the local mammalian community) and compare it to other contemporaneous faunas taken from other European regions. In addition, an analysis with a dataset of recent faunas allows direct comparisons with existing environments for which details of climatic parameters are known (Legendre 1989; Croft 2001; Travouillon and Legendre 2009 and references therein). Carnivore body masses are also reconstructed and help draw conclusions on the structure of the palaeocommunity. Besides, we give a first detailed account of the diversity of this fauna and compare it with the Aquitanian of western Europe to see if palaeobiogeographic or palaeoecological patterns arise.

\section{Materials and methods}

The fauna

The first faunal list for Ulm-Westtangente was published right after its discovery by Heizmann et al. (1989). It was a preliminary list that was enriched later for various groups. Thus, the data we use in this paper come from various sources: for the orders Soricomorpha and Erinaceomorpha and the marsupial, data were published by Ziegler (1989, 1990a, b, 1999a, b) the beaver by Stefen (1997), the other small mammals by Werner (1994), the amphicyonid carnivores by Peigné and Heizmann (2003), other carnivores by Heizmann and Morlo (1994) and Heizmann and Kordikova (2000), the suidae by Hellmund (1991) and the other artiodactyls and perissodactyls were determined by two of us (LC and EPJH, a detailed study of the former is in progress, the preliminary list is given for the first time). It is noteworthy that Werner (1994) described an upper molar of ?Ratufa obtusidens from Ulm-Westtangente. However this M1/2 displays relatively simple and low crests compared to the genus Ratufa. Ratufa is an extant genus of giant squirrels living only in southeastern Asia. Dehm (1950) described a new species of fossil Sciuridae from the Early Miocene of Wintershof-West that he tentatively ascribed to this genus. Aldana-Carrasco (1992) compared this species with Miocene species of the genus Palaeosciurus (a fossil large ground-squirrel) and came to the conclusion that the species $R$. obtusidens might rather be ascribed to Palaeosciurus. Mein and Ginsburg (1997) described for the first time a true fossil species of Ratufa from the Early Miocene of Thailand and confirmed that R. obtusidens is not a giant squirrel, but rather a large ground-squirrel and should be ascribed to another genus. Later authors followed this point of view, and recent fossil discoveries (Qiu and Ni 2006) confirmed that, like their extant representatives, the fossil species of Ratufa seem restricted to southern Asia. We propose here the designation Palaeosciurus? obtusidens for the M1/2 described by Werner (1994, p.171).

Settings and age of Ulm-Westtangente

Heizmann et al. (1989) give a detailed account of the geological settings of the finds. The fossils were discovered within a $35 \mathrm{~cm}$-thick layer of marls of the Lower Freshwater Molasse. The taphonomy was never studied in detail since the excavation took place in a very limited amount of time when the outcrop was open to scientists. Nonetheless, the observations seem to indicate a more or less even distribution of the fossils inside the layer without apparent size sorting. 
In terms of biochronology, the age of Ulm-Westtangente is mainly based on small mammals. Heizmann et al. (1989) based his studies on the ongoing work of Werner and later Werner (1994) gave an Aquitanian age in Zone MN2a. If we look at the small mammal assemblage in detail, the absence of genera Gliravus, Adelomyarion, Rhizospalax and theridomyid rodents (which disappeared at the end of the Oligocene) together with the presence of Paracitellus, Eucricetodon and Pseudocricetodon (which disappeared before the end of the Early Miocene) undoubtedly indicate an Early Miocene age (MN1-MN3; Mein 1999). Then, the affine form of E. gerandianus species, which is restricted to Aquitanian allows refining the Early Miocene age (MN1-2; Hugueney 1999). As stressed by Mein (1999), several insectivores found in Ulm-Westtangente, and absent from the earliest Miocene fossil record (MN1), such as Heterosorex, Soricella, Hugueneyea, Asthenoscapter, Chainodus and Cordylodon, also bring valuable information on the age of the locality. Finally, the species Ritteneria molinae, the existence of which is very limited in time (Engesser 1999) allows a more precise dating by correlating the locality to the MN2a unit. Despite the fact that the genus Pseudoltinomys existed from the Late Oligocene to the end of the Early Miocene, the presence of the species P. parvulus, also known from the locality Haslach (southern Germany, MN2a), supports this biochronological interpretation.

As far as large mammals are concerned, the association of Cephalogale, Mesaceratherium, Dremotherium (the last occurrences of which are known in MN2), Paratapirus, Herpestides and Potamotherium (the first occurrences of which are in MN2) is in accordance with the age indicated by small mammals.

\section{Cenogram}

A cenogram analysis has been applied to Ulm-Westtangente, which yielded enough nonvolant species to interpret a community-based body mass distribution. This method has been successfully applied to various fossil localities along the Cenozoic to infer palaeoenvironments of the Old World (Legendre 1986, 1989; Bonis et al. 1992; Montuire et al. 1997; Costeur 2005; Costeur and Legendre 2008a; Deng 2009), but also to faunas from South America (Croft 2001) and Australia (Travouillon and Legendre 2009). Several of the above-mentioned papers describe the method in detail, including how body masses are inferred from teeth measurements. Individual body mass is a fundamental biological and ecological parameter structuring mammalian communities. Rank-ordered body mass distributions of the species of a community, known as cenograms, have been shown to give much insight into community structure, as well as into the environment inhabited by the community (Legendre 1986, 1989). Teeth measurements were taken either from the literature or directly measured by us (LC and EPJH) for the ruminants and rhinoceroses (see Table 1 for details). The equations used to reconstruct body masses from the lower first molars are from Legendre (1989). We compare the "large" and "small" mammal segments of the cenogram, with a limit at $8 \mathrm{~kg}$, which proved to be efficient. Indeed, cenogram parameters such as this $8-\mathrm{kg}$ gap in body masses seem to be correlated to mean annual precipitation (MAP) levels (Costeur and Legendre 2008a). The latter are indirect good indicators for vegetation density: the smaller the 8-kg gap, the higher is the MAP. Both lagomorphs are not represented on the cenogram because of difficulties in reconstructing body masses of extinct species.

A principal component analysis (PCA) of the proportions of six body mass categories calculated for Ulm-Westtangente and for a sample of extant faunas from Legendre (1989) was carried out using software PAST (Hammer et al. 2001). Body mass categories are adapted from Holling (1992) and extracted for each fauna (1-10 g, 10-100 g, $100-1,000 \mathrm{~g}, 1-10 \mathrm{~kg}, 10-1000 \mathrm{~kg}$ et $>1,000 \mathrm{~kg}$ ). They are analysed together with Ulm-Westtangente. A number of extant very arid, desert or boreal faunas were a priori excluded from the analysis after the result of the faunal inspection showed the presence of a substantial amount of forest inhabitants in the Ulm-Westtangente assemblage. Inclusion of these faunas was actually tested (graph not shown here), but their presence in the result, far from Ulm-Westtangente, yielded too much inertia and their removal was also chosen to better discriminate UlmWesttangente inside the pool of data on extant faunas. Raw proportion data for both extant and extinct samples can be found in the Appendix; raw body masses and faunal lists of extant faunas are found in Legendre (1989) and in an extended dataset available upon request. The PCA is a good quantitative complement to the qualitative study of the cenogram.

Body mass estimates were also calculated for the Carnivora to investigate their position in the overall mammalian community. Estimates of the determined taxa were generated using the equations developed by Legendre and Roth (1988) linking body masses to the surface of the lower first molar. Data either came from measures made by one of us (SP) or from the literature. Data are given in Table 1 together with body masses for the other mammals. Indeterminate musteloid taxa and Cephalogale sp. (a genus which includes species of very different sizes) were assigned body mass ranges based on estimations made on Aquitanian species of the same groups. Due to absence of precise body mass estimates, they do not appear on the cenogram but counted in histograms of body mass categories. The three Musteloidea indet. are thus counted in the 
Table 1 Faunal list of Ulm-Westtangente and body masses used in this study with sources for their computation or estimation

\begin{tabular}{|c|c|c|c|c|c|c|}
\hline Order & Family & Species & $\begin{array}{l}\text { Body } \\
\text { mass }(\mathrm{g})\end{array}$ & Source & Environment & Diet \\
\hline Marsupiala & Didelphidae & Amphiperatherium frequens & 86 & Ziegler (1990a) & $\mathrm{C}$ & ins. \\
\hline Soricomorpha & Plesiosoricidae & Plesiosorex cf. Soricinoides & 160 & $\begin{array}{l}\text { Costeur (2005) based } \\
\text { on Aquitanian Plesiosorex }\end{array}$ & $\mathrm{i}$ & ins. \\
\hline Soricomorpha & Heterosoricidae & Heterosorex neumayrianus & 23 & Ziegler (1989) & $\mathrm{i}$ & ins. \\
\hline Soricomorpha & Soricidae & Crocidosorex sp. & 123 & Ziegler (1989) & $\mathrm{i}$ & ins. \\
\hline Soricomorpha & Soricidae & Soricella cf. Discrepans & 7 & Ziegler (1989) & $\mathrm{i}$ & ins. \\
\hline Soricomorpha & Soricidae & Crocidosorex antiquus & 4 & Ziegler (1989) & $\mathrm{i}$ & ins. \\
\hline Soricomorpha & Talpidae & Geotrypus montisasini & 33 & Ziegler (1989) & $\mathrm{O}$ & ins. \\
\hline Soricomorpha & Talpidae & Mygalea jaegeri & 22 & Ziegler (1989) & $\mathrm{i}$ & ins. \\
\hline Soricomorpha & Talpidae & Hugueneya aff. Primitiva & 21 & Ziegler (1989) & $\mathrm{O}$ & ins. \\
\hline Soricomorpha & Talpidae & Paratalpa meyeri & 19 & Ziegler (1989) & $\mathrm{O}$ & ins. \\
\hline Soricomorpha & Talpidae & Asthenoscapter sp. & 9 & Ziegler (1989) & $\mathrm{i}$ & ins. \\
\hline Soricomorpha & Talpidae & Myxomygale minor & 5 & Ziegler (1989) & $\mathrm{i}$ & ins. \\
\hline Soricomorpha & Talpidae & Desmanella sp. & 6 & Ziegler (1989) & $\mathrm{i}$ & ins. \\
\hline Soricomorpha & Talpidae & Talpa tenuidentata & 6 & Ziegler (1989) & $\mathrm{O}$ & ins. \\
\hline Erinaceomorpha & Dimylidae & Chainodus ulmensis & 145 & Ziegler 1990a & $\mathrm{i}$ & ins. \\
\hline Erinaceomorpha & Dimylidae & Pseudocordylodon cf. vireti & 58 & Ziegler (1990a) & $\mathrm{i}$ & ins. \\
\hline Erinaceomorpha & Dimylidae & Cordylodon sp. & $40-60$ & Ziegler (1990a) & $\mathrm{i}$ & ins. \\
\hline Erinaceomorpha & Dimylidae & Dimylus paradoxus & 43 & Ziegler (1990a) & $\mathrm{i}$ & ins. \\
\hline Rodentia & Gliridae & Glis truyolsi & 54 & Werner (1994) & $\mathrm{C}$ & herb. \\
\hline Rodentia & Gliridae & $\begin{array}{l}\text { Bransatoglis infralactorensis } \\
\text { ingens }\end{array}$ & 34 & Werner (1994) & $\mathrm{C}$ & herb. \\
\hline Rodentia & Gliridae & Plesiodyromys toriformis & 18 & Werner (1994) & $\mathrm{C}$ & herb. \\
\hline Rodentia & Gliridae & Peridyromys obtusangulus & 17 & Werner (1994) & $\mathrm{C}$ & herb. \\
\hline Rodentia & Gliridae & Peridyromys aff. murinus & 15 & Werner (1994) & $\mathrm{C}$ & herb. \\
\hline Rodentia & Gliridae & Microdyromys hildebrandti & 6 & Werner (1994) & $\mathrm{C}$ & herb. \\
\hline Rodentia & Sciuridae & Palaeosciurus? obtusidens & 355 & Werner (1994) & $\mathrm{O}$ & herb. \\
\hline Rodentia & Sciuridae & Palaeosciurus cf. feignouxi & 201 & Werner (1994) & $\mathrm{O}$ & herb. \\
\hline Rodentia & Sciuridae & Blackia ulmensis & 69 & Werner (1994) & $\mathrm{C}$ & herb. \\
\hline Rodentia & Sciuridae & Heteroxerus aff. paulhiacensis & 40 & Werner (1994) & $\mathrm{O}$ & herb. \\
\hline Rodentia & Aplodontidae & Paracitellus eminens & 370 & Werner (1994) & $\mathrm{C}$ & herb. \\
\hline Rodentia & Eomyidae & Pseudotheridomys parvulus & 8 & Werner (1994) & $\mathrm{C}$ & herb. \\
\hline Rodentia & Eomyidae & Ritteneria molinae & 10 & Werner (1994) & $\mathrm{C}$ & herb. \\
\hline Rodentia & Castoridae & Steneofiber eseri & 2931 & Stefen (1997) & $\mathrm{C}$ & herb. \\
\hline Rodentia & Cricetidae & Eucricetodon aff. gerandianus & 44 & Werner (1994) & $\mathrm{C}$ & herb. \\
\hline Rodentia & Cricetidae & Pseudocricetodon thaleri & 16 & Werner (1994) & $\mathrm{C}$ & herb. \\
\hline Lagomorpha & Ochotonidae & Eurolagus ulmensis & $300-400$ & Based on living ochotonids & $\mathrm{O}$ & herb. \\
\hline Lagomorpha & Ochotonidae & Titanomys visenoviensis & $300-400$ & Based on living ochotonids & $\mathrm{O}$ & herb. \\
\hline Perissodactyla & Rhinocerotidae & $\begin{array}{l}\text { Mesaceratherium cf. } \\
\text { paulhiacense }\end{array}$ & 1752395 & This study (E.P.J.H. 2011) & $\mathrm{O}$ & herb. \\
\hline Perissodactyla & Rhinocerotidae & $\begin{array}{l}\text { Protaceratherium cf. } \\
\text { minutum }\end{array}$ & 590149 & This study (E.P.J.H. 2011) & $\mathrm{C}$ & herb. \\
\hline Perissodactyla & Chalicotheriidae & cf. Metaschizotherium wetzleri & 194143 & Koenigswald (1932) & $\mathrm{O}$ & herb. \\
\hline Perissodactyla & Tapiridae & Paratapirus intermedius & 117536 & this study (E.P.J.H. 2011) & $\mathrm{C}$ & herb. \\
\hline Cetartiodactyla & Suidae & Hyotherium meissneri & 70054 & Hellmund (1991) & $\mathrm{C}$ & omn. \\
\hline Cetartiodactyla & Cainotheriidae & Cainotherium cf. laticurvatum & 2261 & This study (E.P.J.H. 2011) & $\mathrm{C}$ & herb. \\
\hline Cetartiodactyla & Family indet. & Dremotherium feignouxi & 26300 & This study (L.C. 2011) & $\mathrm{O}$ & herb. \\
\hline Cetartiodactyla & Family indet. & Amphitragulus cf. elegans & 24378 & This study (L.C. 2011) & $\mathrm{C}$ & herb. \\
\hline Cetartiodactyla & Family indet. & Pomelomeryx boulangeri & 10205 & This study (E.P.J.H. 2011) & $\mathrm{C}$ & herb. \\
\hline
\end{tabular}


Table 1 continued

\begin{tabular}{|c|c|c|c|c|c|c|}
\hline Order & Family & Species & $\begin{array}{l}\text { Body } \\
\text { mass }(g)\end{array}$ & Source & Environment & Diet \\
\hline Cetartiodactyla & Family indet. & Pomelomeryx gracilis & 7951 & This study (E.P.J.H. 2011) & $\mathrm{C}$ & herb. \\
\hline Carnivora & Amphicyonidae & Haplocyonoides suevicus & 55000 & Peigné and Heizmann (2003) & $\mathrm{i}$ & carn. \\
\hline Carnivora & Amphicyonidae & Cynelos lemanensis & 65000 & Peigné and Heizmann (2003) & $\mathrm{i}$ & carn. \\
\hline Carnivora & Amphicyonidae & Cynelos cf. helbingi & 61000 & $\begin{array}{l}\text { This study (S.P. 2011) based } \\
\text { on type material }\end{array}$ & $\mathrm{i}$ & carn. \\
\hline Carnivora & Amphicyonidae & Ysengrinia gerandiana & 89000 & This study (S.P. 2011) & $\mathrm{i}$ & carn. \\
\hline Carnivora & Amphicyonidae & Crassidia intermedia & 190000 & This study (S.P. 2011) & $\mathrm{i}$ & carn. \\
\hline Carnivora & Ursidae & Cephalogale sp. & $10-100 \mathrm{~kg}$ & This study (S.P. 2011) & $\mathrm{i}$ & carn. \\
\hline Carnivora & Ailuridae & Amphictis schlosseri & 3900 & This study (S.P. 2011) & $\mathrm{i}$ & carn. \\
\hline Carnivora & Viverridae & Herpestides sp. & 3750 & $\begin{array}{l}\text { This study (S.P. 2011) based } \\
\text { on H. antiquus, St-Gérand-le-Puy }\end{array}$ & $\mathrm{i}$ & carn. \\
\hline Carnivora & Musteloidea & Potamotherium sp. & 4250 & $\begin{array}{l}\text { This study (S.P. 2011) based } \\
\text { on P. valletoni, } \\
\text { St-Gérand-le-Puy }\end{array}$ & $\mathrm{i}$ & carn. \\
\hline Carnivora & Musteloidea & Palaeogale sp. & ca. 500 & $\begin{array}{l}\text { This study (S.P. 2011) based } \\
\text { on Aquitanian Palaeogale }\end{array}$ & $\mathrm{i}$ & carn. \\
\hline Carnivora & Musteloidea & indet. & $1-10 \mathrm{~kg}$ & This study (S.P. 2011) & $\mathrm{i}$ & carn. \\
\hline Carnivora & Musteloidea & indet. & $1-10 \mathrm{~kg}$ & This study (S.P. 2011) & $\mathrm{i}$ & carn. \\
\hline Carnivora & Musteloidea & indet. & $1-10 \mathrm{~kg}$ & This study (S.P. 2011) & $\mathrm{i}$ & carn. \\
\hline
\end{tabular}

Categories used for Fig. 4 are also given: Environment ( $C$ closed, $O$ open, $i$ indeterminate); Diet (ins. insectivore, herb. herbivore, omn. omnivore, carn. carnivore)

$1-10 \mathrm{~kg}$ category and Cephalogale sp. in the $10-100 \mathrm{~kg}$ category.

\section{Results}

Composition of the fauna

Ulm-Westtangente is one of the two richest faunas of the Aquitanian of Europe. The second one is Montaigu-le-Blin in the Allier Basin in France, which is also the reference locality of Zone MN2a. Indices of stratigraphic mixing of the material for the latter make it difficult to fully understand. Thus, Montaigu-le-Blin is often mentioned simply as "Saint-Gérand-le-Puy", a basin that has yielded fossils from level MP29 to zone MN2. In this case, the fauna of Ulm-Wettangente being the result of an excavation into a $35 \mathrm{~cm}$-thick layer of sediments, the limited time averaging associated with the finds makes it a great source of information for the knowledge of the Aquitanian faunas of Europe. The mammal faunal list was preliminarily given in Heizmann et al. (1989) and subsequent taxonomic studies enriched its knowledge. Together with recent works on carnivores and an ongoing study on ruminants, 61 species of mammals within 55 genera and 25 families were identified so far. Figure 1 gives a quantitative and proportional account of the whole fauna and Table 1 lists all the non-flying mammal species (bats are represented by three indeterminate species). What is interesting to note is that the fauna is dominated by three orders: first Rodentia (16 species), and then Carnivora and Soricomorpha (each with 13 species). Large herbivores are still well represented with a chalicothere, a tapir, two rhinoceroses and six artiodactyls and dominated by primitive ruminants. The latter are put into a "family indet." category rather than in the usual family Moschidae, since no relevant morphological characteristics really confirm this assignment (Sánchez et al. 2010).

Carnivores are represented by at least 13 species in 5 families (Fig. 1; Table 1), sometimes still indeterminate, which is much less than that in the published lists of Montaigu-le-Blin (22 species; Hugueney 1997), and more or less the same as in Paulhiac and Laugnac. As mentioned above, however, the faunal list of Montaigu-le-Blin may encompass faunas of different stratigraphical levels or at least different sites, as taxa from Langy, for example, are sometimes included within the same faunal list as Montaigu-le-Blin (see, e.g. Hugueney 1997). The faunal list of Ulm-Westtangente includes five to seven species of Amphicyonidae belonging to two subfamilies (Amphicyoninae and Haplocyoninae) and at least four genera. Other taxa belong to the Viverridae (Herpestides sp.), the Ursidae (Cephalogale sp.), the Ailuridae (Amphictis schlosseri) and basal lineages of Musteloidea (up to 5 species, including at least Palaeogale sp. and Potamotherium sp.). So far, only 
Fig. 1 Faunal target for UlmWesttangente; figures indicate number of species

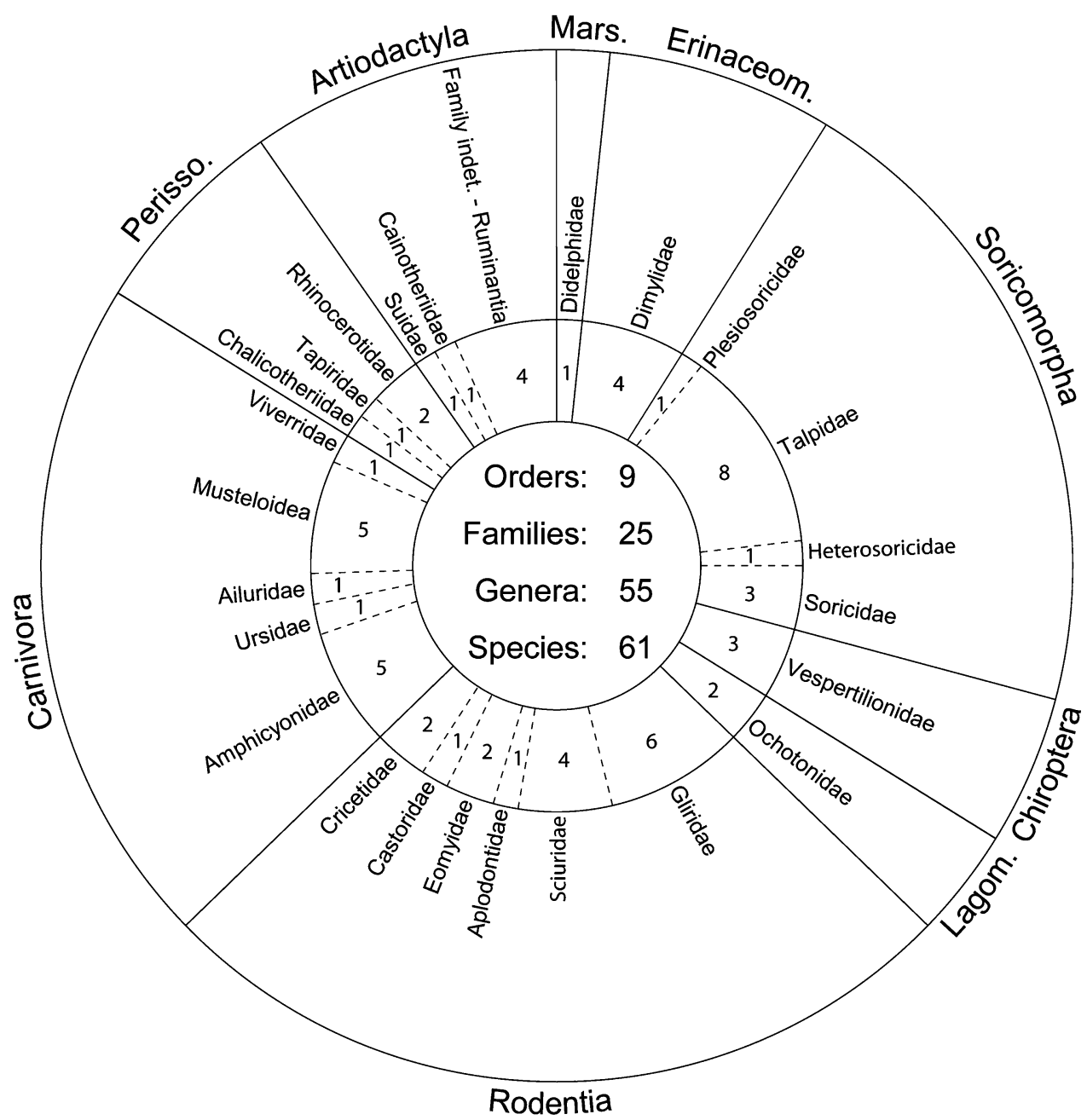

the Amphicyonidae and the Ailuridae have been studied in detail (Heizmann and Morlo 1994; Heizmann and Kordikova 2000; Peigné and Heizmann 2003). Other taxa are either known from fragmentary material not diagnostic at the species level or remain to be studied (see Heizmann 1998; Heizmann et al. 1989). The carnivore fauna of UlmWesttangente is mostly similar to that of Montaigu-le-Blin. All the families and genera present in Ulm-Westtangente, with the exception of the amphicyonid Haplocyonoides, are also known from Montaigu-le-Blin. The major characteristic of the carnivore fauna from Ulm-Westtangente is the high diversity of the family Amphicyonidae. For the Early Miocene, a similar diversity was only found in Montaigule-Blin, Laugnac and Paulhiac, but it is with the first of these sites that Ulm-Westtangente shares the most similarities, with three species present in common: Crassidia intermedia, Cynelos lemanensis and Ysengrinia gerandiana. Compared to the French site, however, Ulm-Westtangente has yielded (1) an endemic species of the rare genus Haplocyonoides, which is the most derived taxon of the subfamily Haplocyoninae (2 species of the plesiomorphic Haplocyon are present at Montaigu-le-Blin and Paulhiac, while Haplocyon and Haplocyonoides are present in Laugnac) and (2) a species of Cynelos very close to C. helbingi from Wintershof-West (MN3), while C. rugosidens is known from Montaigu-le-Blin and Laugnac. Beside Ulm-Westtangente, the ailurid Amphictis schlosseri (see Morlo and Peigné 2010) is only present in the Mainz Basin (Heizmann and Morlo 1994), but close relatives are present in France (e.g. Montaigu-le-Blin, Laugnac). The only family present in Montaigu-le-Blin, Laugnac and Paulhiac that is not represented in Ulm-Westtangente is the Felidae. Early felids, Proailurus spp. are present, although they are never abundant, in France from the late Oligocene (Quercy, Coderet, and possibly Chaptuzat) to zone MN2 in the Saint-Gérand-Basin and Laugnac; outside France, the genus is rare and known only from the Mainz Basin, with Proailurus bourbonnensis (Bonis et al. 1999; Peigné 1999). At a genus level, the main feature of the Ulm-Westtangente fauna is the presence of Haplocyonoides (versus Haplocyon 
and/or Haplocyonopsis in, e.g. Montaigu-le-Blin and Paulhiac), with a species represented by a relatively good sample compared to the general scarcity of Haplocyoninae in the fossil record. Another species of Haplocyonoides is however present at Laugnac. Amphictis schlosseri (UlmWesttangente and Main basins) is the only taxon to also have a relative limited distribution. Compared to many early Miocene localities, Plesictis has not yet been identified in Ulm-Westtangente, but might be present in the indeterminate material. Other determined taxa, Palaeogale, Herpestides and Potamotherium, are usual findings in early Miocene localities of Europe. The subordinal taxonomic diversity of the carnivore fauna of Ulm-Westtangente follows the general trend already observed in France (Peigné 2000), i.e. the abundance of caniforms and the scarcity of feliforms. Like in Paulhiac (Proailurus only), the proportion is even extreme in Ulm-Westtangente since only one feliform, the viverrid Herpestides, has been identified. The other rich early Miocene faunas from Europe (e.g. Laugnac, Montaigu-le-Blin, Mainz Basin) generally have yielded two or more genera of feliforms (three or more species): the felid Proailurus (e.g. Laugnac, Montaigu-le-Blin, Mainz Basin), the viverrids Herpestides (Montaigu-le-Blin, Mainz Basin) and Semigenetta (Laugnac), the hyaenid Plioviverrops (Laugnac) and the basal feliforms Viretictis (Mainz Basin, Montaigu-le-Blin).

As far as large herbivorous mammals are concerned, ten species are recorded including a chalicothere, two rhinoceroses, a tapir, a suid, a cainothere and most probably four small antlerless ruminants (Fig. 1; Table 1). So far and despite exquisite material, only the suid has been extensively studied (Hellmund 1991) and a study in progress (Costeur and Heizmann) will describe the abundant ruminant material. No species is totally endemic to UlmWesttangente, one of the most geographically restricted species would be cf. Metaschizotherium wetzleri otherwise only known in Eggingen, Michelsberg and Tuchorice (but the status of Early Miocene chalicotheres is still debated; Heissig 1999) and to a lesser extent Mesaceratherium cf. paulhiacense with records only in Germany, France and possibly Switzerland (pers. com. Damien Becker). The other rhinoceros Protaceratherium minutum is much more largely distributed across the European continent with records in various regions of France, Spain, Germany and Switzerland. The tapir Paratapirus intermedius is known from other localities of the German fossil record in Zone MN2 (e.g. Eggingen, Budenheim and Hessler) and also in the French Paris and Aquitanian basins (Selles-sur Cher and Laugnac, respectively) such as that recalled by Scherler et al. (2011). As far as artiodactyls are concerned, several species recorded at Ulm-Westtangente are also found elsewhere. Good correspondance can be made between the German locality and other contemporaneous
European localities, especially from France and Switzerland. In France, the richest Aquitanian faunas are Montaigu-le-Blin and Laugnac, as mentioned above. Ulm-Westtangente has several species in common with Montaigu-le-Blin such as Dremotherium feignouxi, Amphitragulus cf. elegans, Pomelomeryx gracilis, P. boulangeri, Cainotherium cf. laticurvatum and Hyotherium meissneri, and with Laugnac: D. feignouxi and $P$. gracilis. Only the suid $H$. meissneri seems to be part of the MN2 Spanish record (Cetina de Aragon) testifying to significant biogeographic differences between southern Europe and the German regions at this time (Costeur et al. 2004). The large herbivorous components of the Ulm-Westtangente fauna show a typical Early Miocene situation with species inherited from the Late Oligocene European faunas. The presence of the chalicothere is the first indication of the late Early and Middle Miocene faunal renewal that would occur.

The small mammals' assemblage is composed of 1 species of marsupial, 3 indeterminate vespertilionid bats, 17 "insectivores" (13 Soricomorpha and 4 Erinaceomorpha) and 16 rodents (Fig. 1; Table 1). If on one hand some taxa, such as Amphiperatherium frequens or Peridyromys murinus, are common and widely distributed in the Early Miocene of Europe, some other taxa are geographically more restricted or even indicate a relative level of endemism of Ulm-Westtangente. For what concerns insectivores, one of the particularities of Ulm-Westtangente compared to other Early Miocene localities is in having four species of Dimylidae and three species of Desmaninae, whereas these groups are relatively rare elsewhere (Ziegler 1999a, b). The species Chainodus ulmensis is only known from Ulm-Westtangente. In the Early Miocene, the genera Chainodus, Dimylus, Pseudocordylodon, Asthenoscapter, Desmanella and Mygalea are mainly known from the northern and northeastern parts of Europe (Germany, France, Switzerland, Czech Republic and Austria). However, Desmanella and Chainodus have also been identified in the Early Miocene locality of Rubielos de Mora 2 (Spain; Montoya et al. 1996). Likewise in Europe, the Aquitanian Plesiosorex is also restricted to the fossil record of Germany and France. Among the Talpidae, the genera present in Ulm-Westtangente are generally more widely distributed across Europe; however, the species Talpa tenuidentata and Myxomygale minor are so far endemic to Ulm-Westtangente; furthermore, Paratalpa meyeri and Geotypus montisasini seem restricted to the fossil record of Germany. The soricids are generally more widely distributed and none of them is endemic to Ulm-Westtangente.

Among the 16 rodents, the family Gliridae is the most diversified with five genera and six species. With the exception of Plesiodyromys which has only been recognised in one other locality (La Chaux 7; Engesser and 
Mödden 1997), other genera found in Ulm-Westtangente (Bransatoglis, Glis, Microdyromys and Peridyromys) are widely distributed across the Early Miocene of Europe, generally from western Europe to the Anatolian region. However, the distributions of the species are generally more restricted to the northwestern or western part of Europe, and the subspecies Bransatoglis infralactorensis ingens is only known from the Early Miocene of Germany and Switzerland.

For what concerns sciurids, the second most diversified rodent family in Ulm-Westtangente, three genera and four species co-existed in the locality: the three genera Heteroxerus, Palaeosciurus and Blackia show a broad geographic distribution in the Early Miocene of Europe, from western Europe to the Anatolian region. However, the species Palaeosciurus? obtusidens is relatively rare in the fossil record of Europe, known in the Early Miocene of Germany (Dehm 1950; Werner 1994) and the locality El Canyet in Spain (Aldana-Carrasco 1992); Blackia ulmensis is only known from two other Early Miocene localities: La Chaux 7 (Switzerland; Engesser and Mödden 1997) and Jungingen (Germany; Werner 1994). Other families of rodents in Ulm-Westtangente are less diversified and their species are quite common in the Early Miocene of Europe, with the exception of Paracitellus eminens which is only known from Ulm-Westtangente and Wintershof-West.

This overall mammalian faunal composition is close to that of Montaigu-le-Blin with 22 species, 26 genera and 21 families in common (for Ulm-Westtangente 37, 48 and $84 \%$ of commonness with Montaigu-le-Blin at the three levels, respectively). It is to be noted that the fauna of Montaigu-le-Blin was never revised and the most recently published lists (e.g. Hugueney 1997) are based on old references for several groups (e.g. carnivores, artiodactyls). It thus seems difficult to know now if all the species involved are actually present in Montaigu-le-Blin or even valid. As much as 16 species and 23 genera from UlmWesttangente are also shared by the Swiss Aquitanian locality of La Chaux (MN2; Becker et al., 2002, and pers. obs.), which is the geographically closest locality with a large faunal spectrum known at this time period. Other localities like Laugnac or Cetina de Aragon presented in Fig. 2 as cenograms show good levels of taxonomic affinity, but to a much lesser extent than Montaigu-le-Blin and La Chaux.

Ecological requirements of constituting species

Forest environments are represented by a number of species including the rhinoceros Protaceratherium cf. minutum, which seems to be typical of humid forests to woodlands (Becker 2003). Amphitragulus and Pomelomeryx are small ruminants morphologically close to tragulids and thus a forest habitat was postulated for these animals (Janis and Scott 1987), while Dremotherium seems to have been a higher type of browser that may have frequented more open forests (see also Mennecart et al. 2012, this volume). Chalicotheres and especially schizotheriines are known to be animals of open woodlands (Heissig 1999) and suids and tapirs are more closely related to forest habitats.

Blackia is a flying squirrel and as such testifies to the presence of forested areas. Furthermore, glirids and eomyids have been considered by various authors as having similar ecological requirements, mostly being forest dwellers (e.g. Hugueney 1984; Daams et al. 1988; van der Meulen and Daams 1992). Most of the extant glirids are indeed agile climbers and live in forest environments (Nowak 1995). However, as stated by Engesser (1999) regarding eomyids, if on one hand the forest habitat is suitable for Eomys quercyi due to its adaptation to gliding (Storch et al. 1996), on the other hand all eomyids do not necessarily have the same ecological requirements (Engesser 1990). However due to their rather simple tooth morphology, low tooth crown and their similarities with the genus Eomys, Ritteneria and Pseudotheridomys are likely to indicate a forest environment like glirid species.

Small mammals adapted to open landscapes are less diversified but still well represented at Ulm-Westtangente. Palaeosciurus? obtusidens, Palaeosciurus cf. feignouxi and Heteroxerus aff. paulhiacensis are all ground squirrels, indicating a partly open component of the environment. Talpinae are also adapted to fossorial life in rather open environments like prairies or floodplains, excluding the possibility of a too dry environment.

A number of species are typical of humid conditions. The beaver Steneofiber and the desman insectivores (Asthenoscapter, Desmanella and Mygalea) are all semiaquatic adapted mammals indicating the presence of permanent and/or temporary lakes and rivers in the UlmWesttangente area at the time confirmed by the sediments of the USM (Lower Freshwater Molasse). Hürzeler (1944) considered most taxa of dimylids as being specialised in eating molluscs due to their specialised dentition. With regard to its very amblyodontous teeth morphology, Chainodus might even be adapted to feed on shell producing molluscs (Ziegler 1999a, b) such as gasteropods or bivalves. Together with other molluscs, they are generally associated with humid and even aquatic environments.

Analysis of body masses

The body mass distribution of the herbivore fauna of UlmWesttangente shows a long series of small mammals below $500 \mathrm{~g}$ giving a very low slope to this segment (Fig. 2). This is rather related to environments with forests or forest 


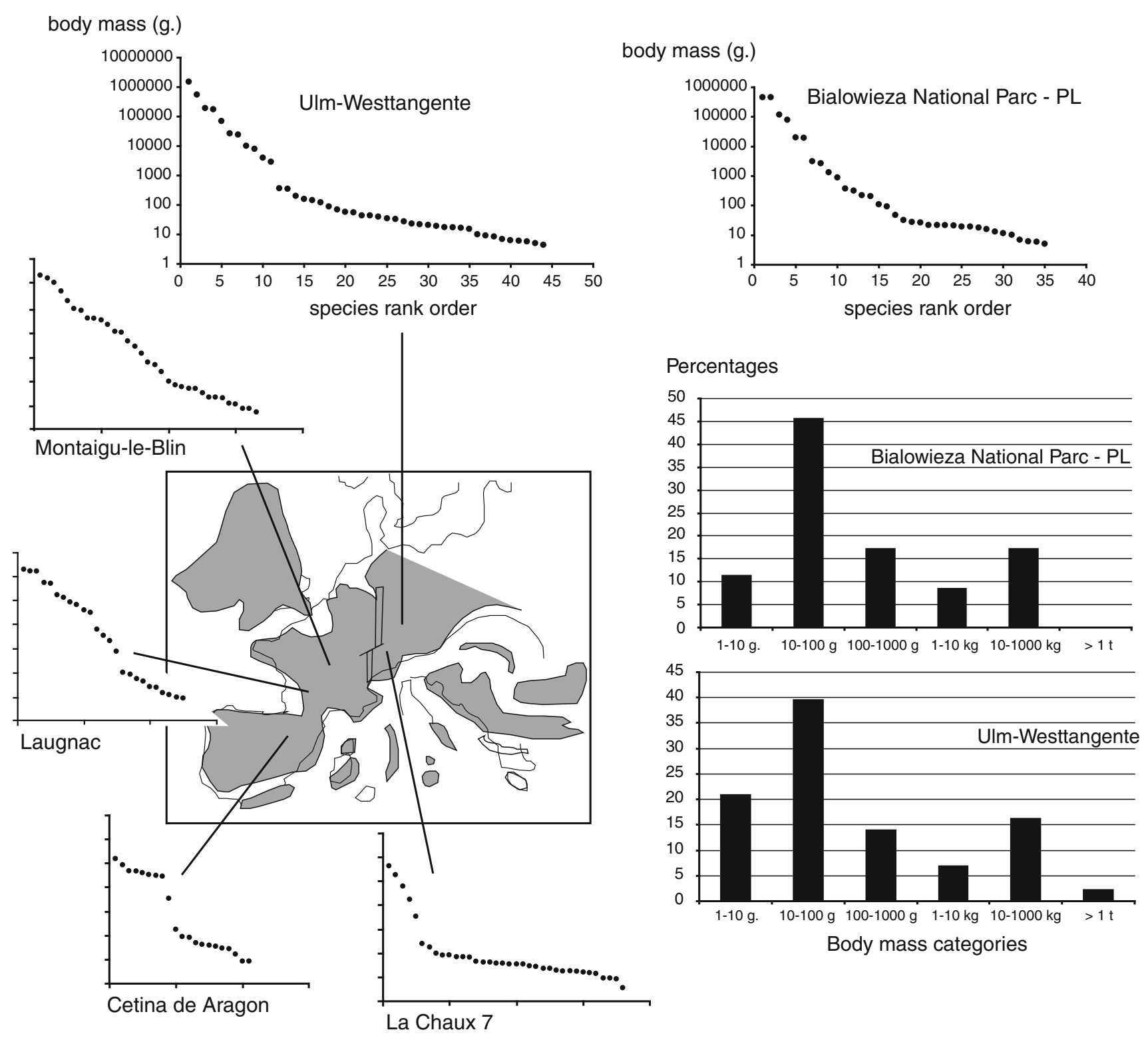

Fig. 2 Cenogram of Ulm-Westtangente compared to the Polish Bialowieza National Parc clustering closer to Ulm-Westtangente in the principal component analysis (see Fig. 3). Fossil faunas of the MN2 biozone are also compared to Ulm-Westtangente and their geographic positions are located on a palaeomap (after Rögl 1999).

patches. The gap at mid-sizes is not very large $(0.9$ in log value for the gap at $500 \mathrm{~g}$. sensu Legendre 1989; and only 0.3 in $\log$ value for the gap at $8 \mathrm{~kg}$. sensu Costeur and Legendre 2008a) and thus indicates the presence of a certain level of humidity. Larger gaps indeed indicate arid conditions such as in the Middle Miocene of Spain, for instance (Costeur and Legendre 2008a). The segment represented by large mammals does not show the same slope as that for small mammals; fully forested or closed conditions can thus be rejected. The presence of open areas
Data for cenograms of fossil faunas are taken from Costeur (2005). Histograms show a comparison of the distribution of species richness expressed as percentages (data used in the PCA, Fig. 3) between UlmWesttangente and the Polish temperate forest

is highly supported by the cenogram. There are few early Aquitanian localities that compare to Ulm-Westtangente in terms of diversity; Montaigu-le-Blin from the French Allier basin and La Chaux 7 in Switzerland have a large faunal spectrum and patterns of their cenogram do relate to those of Ulm-Westtangente (Fig. 2). For instance, the large amount of small mammals in the Swiss fauna and the more or less continuous profile in Montaigu-le-Blin are both characteristics indicating the presence of forested areas. La Chaux 7 is closer to Ulm-Westtangente in the rather limited 
suite of large mammals, with a typical steep slope in this segment and indicating the presence of open areas. The inferred conditions were probably not very humid. Other MN2 faunas such as Laugnac in the Aquitaine Basin and Cetina de Aragon in Spain (Ebro Basin) are different. Laugnac shows a rather discontinuous profile with overall steeper slopes reflecting lower species richness and probably a more arid climate. The Spanish fauna tends to yield the same interpretation with large gaps in the mid-sizes and overall lower species richness; a rather open and rather arid environment may thus be suggested, but biases in the fossil record may not be excluded.

The result of the PCA run on a dataset of body mass proportions of recent faunas from various environments (Appendix) clusters the Ulm-Westtangente fauna with faunas of temperate forests to tropical grasslands and woodlands (Fig. 3a, b). The closest faunas clustering with Ulm-Westtangente are faunas of temperate forests and grasslands found in Poland, like the Bialowieza National Park for which we also give the cenogram and the distribution of body masses (Fig. 2). Both cenograms look close to one another, but that of Ulm-Westtangente has a larger gap at mid-sizes probably indicating more arid and/or more open conditions. The body mass distributions after Holling (1992) are almost similar (Fig. 2). Ulm-Westtangente shows the presence of a megaherbivore (sensu Fritz et al. 2002) which is not found in the European temperate forests and that might testify to more open characteristics (today's large rhinoceroces are open landscape inhabitants). The large European bison does inhabit eastern European temperate forests such as the Bialowieza National Park, but is not a typical megaherbivore. In addition, the bison is a reintroduced species in this park. The extant fauna taken as example here inhabits a temperate forest with a typical temperate climate: mean annual temperature (MAT) of about $7^{\circ} \mathrm{C}$ with negative winter temperatures and mean annual precipitation levels of about $600 \mathrm{~mm}$.

If one investigates the distribution of the species through body size categories in relation to their broad diet category or ecological requirements (i.e. "Environment" on Fig. 4), small species under $100 \mathrm{~g}$ mostly have an insectivorous diet. Species with a herbivorous diet are distributed all along the size range. They are the only ones of large sizes since no insectivore species is bigger than ca. $200 \mathrm{~g}$. Closed environments are represented along the whole body size spectrum, except for very large species or only slightly for small-sized species in the $100 \mathrm{~g}-1 \mathrm{~kg}$ range. Interestingly, all the species of the $1-10 \mathrm{~kg}$ range are closed habitat adapted (in Fig. 4, "indeterminate" in the 1-10 kg category are carnivores for which it is difficult to give environmental requirements). Open environment-adapted species are also found over the whole size range. Unfortunately, indeterminate environmental affinities for several species do alter the signal (see Table 1). Carnivores are mostly found in the mid-sizes to large sizes, such as those figured on the cenogram (Fig. 4) and no carnivore species under probably a few hundred grams is known (Palaeogale sp.). A single carnivore exceeds $100 \mathrm{~kg}$, but still lies well below the $1,000 \mathrm{~kg}$ upper limit of the considered range (Crassidia intermedia, $190 \mathrm{~kg}$ ). In the cenogram, the distribution of body size with species rank order for Carnivora shows a main gap between species smaller than $10 \mathrm{~kg}$ and those considerably larger. The real position of this gap is difficult to set, since some carnivore taxa, which are indeterminate, are not included in the cenogram. Within extant Carnivora, Carbone et al. (1999) identified a mass of $21.5 \mathrm{~kg}$ as the point where carnivores shift from small to large prey (i.e. of their own size or greater), due to both physiological and ecological reasons. Once the indeterminate carnivore material of Ulm-Westtangente has been more precisely ascribed, it would be interesting to observe how consistent the body size gap is within the carnivore guild at Ulm-Westtangente with the value proposed by Carbone and colleagues. We then will be able to determine whether this $21.5 \mathrm{~kg}$ limit only concerns the dietary ecology of carnivores or also involves the structure of the carnivore guild, in particular, the body mass distribution of taxa within the same community.

\section{Discussion}

Aquitanian faunal context

The early Aquitanian faunal context is that of a mainly Oligocene-inherited situation, for carnivores and other mammals; most families and genera were already present at the end of the Oligocene and were still dominant in the Early Miocene. For herbivores, this situation changed just after zone MN2 when Asian and African immigrants entered Europe (see Maridet and Costeur 2010 for a review). Overall, the Early Aquitanian situation is known from a relatively low number of rich localities, such as Cetina de Aragon (Spain), Paulhiac, Laugnac, Montaigule-Blin (France) or La Chaux 7 (Switzerland). Ulm-Westtangente fills in a gap towards eastern Europe and allows completing the picture. It attests to the same basic faunal context with few differences to other European regions (Costeur et al. 2004; Maridet et al. 2007). The MN2 richest faunas in Europe (Montaigu-le-Blin, Laugnac, Cetina de Aragon, La Chaux 7) do indeed indicate a faunal homogeneity albeit also showing some sort of east-west diversity gradient. Lower species richnesses towards southeastern Europe are evidenced; indeed, a number of families are absent in the southeastern regions such as tapirs and chalicotheres (Costeur and Legendre 2008b). 


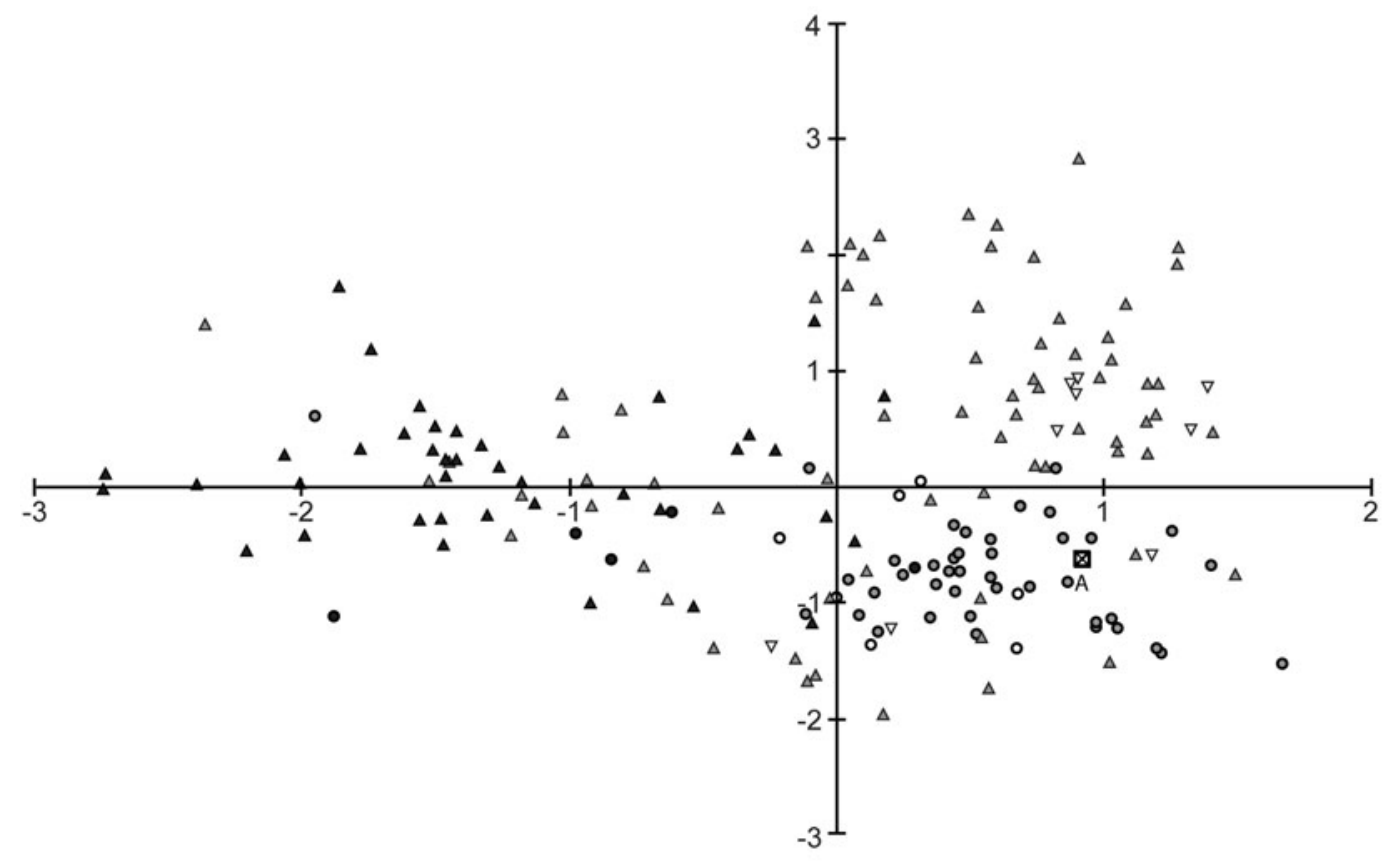

B

$35.7 \%$

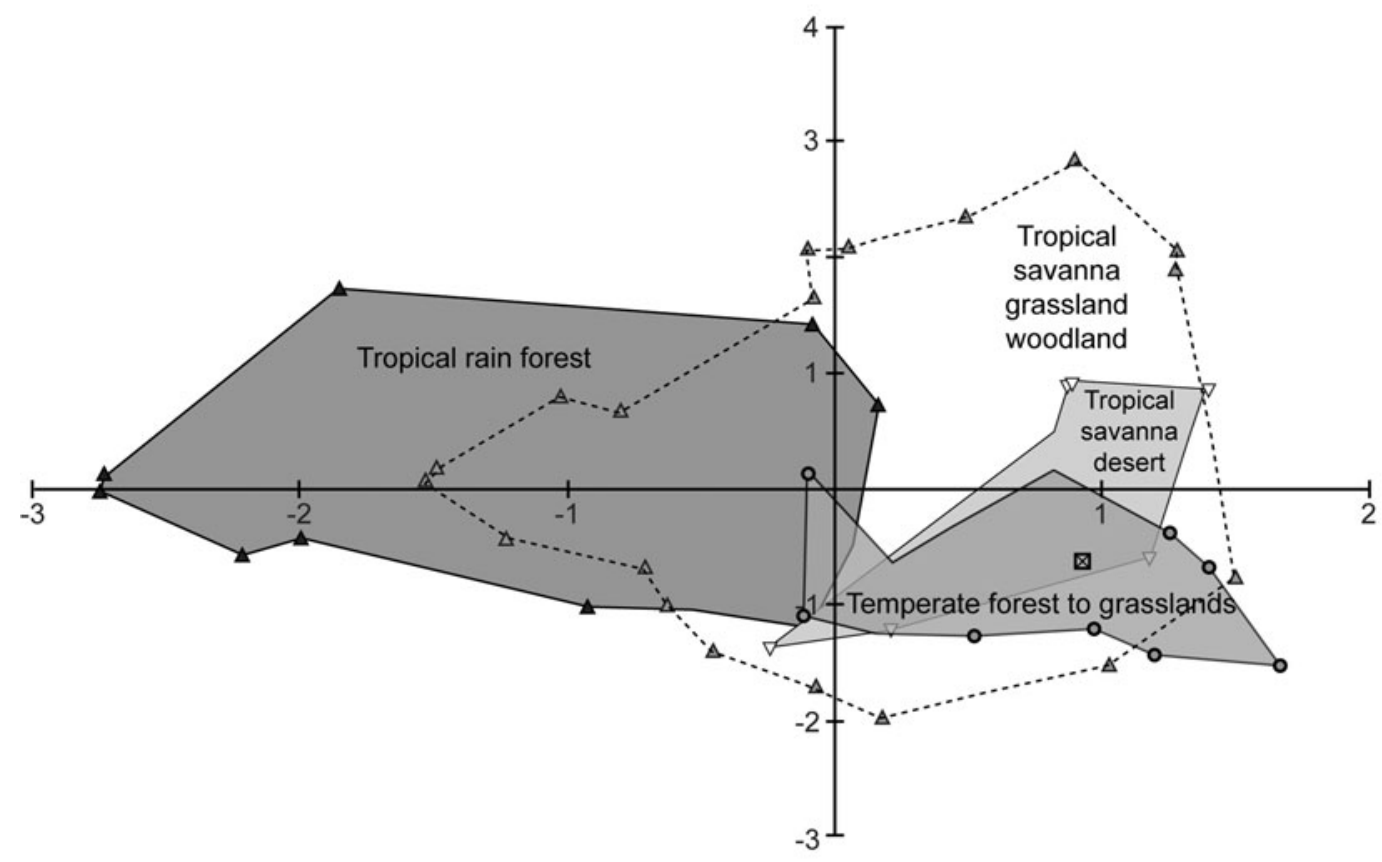

$45.4 \%$

\begin{tabular}{|ll}
\hline $\boldsymbol{\Delta}$ & Ulm-Westtangente \\
$\nabla$ & Tropical savanna-desert \\
$\Delta$ & Tropical rain forest \\
$\Delta$ & Tropical savanna-grassland-woodland
\end{tabular}
A Bialowieza National Parc, PL
- Temperate grassland-desert-steppe
- Temperate montain forest
- Temperate forest s.l.

Fig. 3 Principal component analysis performed on a dataset of relative proportions of body mass categories compiled for recent faunas and Ulm-Westtangente. a Raw data, b clouds for broad environmental types, legends in clouds summarise finer environmental types that are indicated in the framed caption (e.g. "temperate forest to grasslands" stands for the 3 temperate environments of a). The crossed squarre is Ulm-Westtangente 
Fig. 4 Histograms of the distribution of species richness (expressed in proportion of species for "Environment" and "Diet") in Ulm-Westtangente; species are classified according to their body mass categories adapted from Holling (1992). Carnivores are here included and appear as grey stars on the cenogram of Ulm-Westtangente (top)
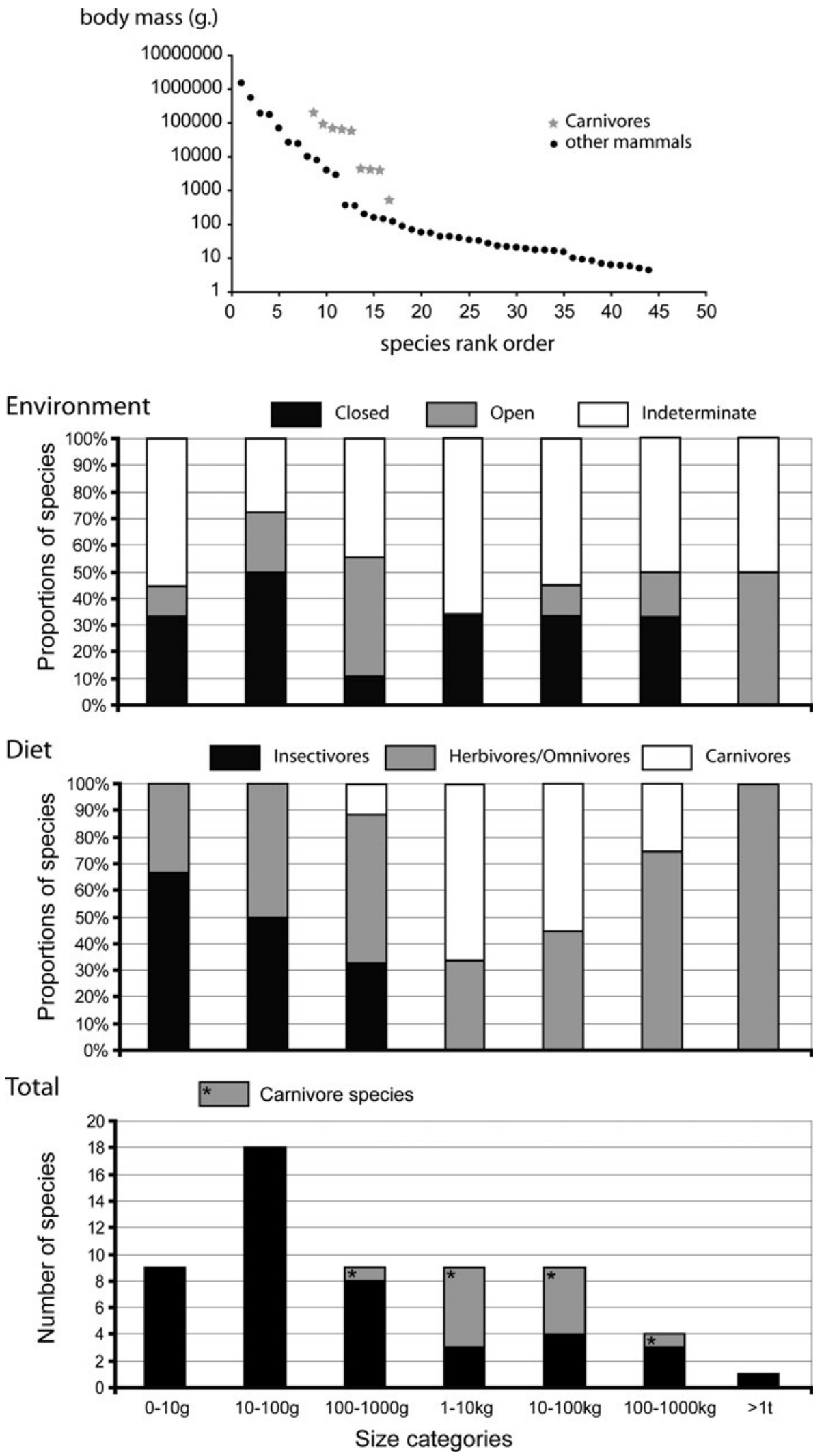

However, the latter study actually failed to find any statistically significant diversity gradient at this time period over the European continent. As far as carnivores are concerned, the typical Early Miocene balance between caniforms and feliforms in favour of the first group is also well defined in Ulm-Westtangente. 
The Aquitanian of Europe: a steady climate?

While several palaeoclimatic studies included the Burdigalian or the Early Miocene as a whole (e.g. Böhme et al. 2011; Ivanov et al. 2011; Jiménez-Moreno et al. 2005; Jiménez-Moreno et al. 2008; Utescher et al. 2000), surprisingly few studies focused on the Aquitanian of Europe itself.

Mosbrugger et al. (2005) indicate warm-temperate conditions with possible short-term cooling events in the very Early Miocene of Central Europe based on an analysis of plant micro and macro-fossils. Such an evolution from temperate to warm conditions was also proposed by Hugueney (1984) based on the regional analysis of the central French localities of the Allier Basin. This study indicated an environmental evolution across the OligoceneMiocene boundary with a change from colder and more arid conditions at the very end of the Oligocene to somewhat more humid conditions in the Miocene. Otherwise, other studies generally suggest a steady warm and humid climate across the whole Early Miocene. Ivanov et al. (2011) indicate a warm and humid climate in the Aquitanian of Central Europe with altitudinal belts related to the Carpathian Mountains. Subtropical forests and swamps in the lowland and warm-temperate forests on the slopes are interpreted. Reconstructed MATs are high with about $16^{\circ} \mathrm{C}$ and mean cold month temperatures are never negative in a humid context of high MAP (Ivanov et al., 2011). Likewise, Larsson et al. (2010) found a warm-temperate climate further north at the base of the Aquitanian in what is now Denmark with MATs of around $16^{\circ} \mathrm{C}$. The Swiss fossil record yielded Aquitanian localities that also testify to subtropical grassland to savanna environments: the localityWallenried (zone MN2b) probably had year-round humidity and few seasonal temperature variations (Becker et al. 2001). Another MN2 Swiss locality, Engehalde, indicates a grassland-woodland habitat with riparian forests (Becker et al. 2010). In contrast, if the contribution of pollen samples from southern France indicates a rather subtropical to tropical climate, it also suggests a marked seasonality with sclerophilous forests. The environment was semi-arid in the low plains and an evergreen forest grew in altitude, thanks to higher humidity levels (cloudiness; Bessedik 1984). The analysis of the Early Miocene succession from the Rubielos de Mora Basin (NE Spain, Jiménez-Moreno et al. 2007) also indicates a subtropical and dry seasonal climate in the Aquitanian. More generally, the absence of fossil channid fishes in western Europe prior to the Miocene climatic optimum (Böhme 2004) implies rather low summer precipitation levels and thus a more "arid" climate than later in the Miocene.

In the context of these studies indicating year-round humidity or seasonal aridity, a subtropical or warm- temperate climate, the faunal composition of Ulm-Westtangente seems at first rather difficult to relate to a palaeoclimate. Ulm-Westtangente has indeed a typically mixed fauna with forest dwellers including flying squirrels or small forest-adapted artiodactyls and with grassland dwellers including ground squirrels or a chalicothere. Riparian vegetation can be postulated with the presence of a beaver and of desman soricomorphs. This mosaic of environments postulated for Ulm-Westtangente suggests the existence of variation in seasonal precipitations indicated by other works (Bessedik 1984; Böhme 2004). But it can also possibly witness an ongoing progressive change towards more closed vegetation in the late Early Miocene.

The extant cenogram displaying the closest composition to Ulm-Westtangente (Bialowieza National Parc, Poland) is coherent with mixed vegetation composed of forests and grasslands. If one applies the actualistic principle, this however also surprisingly suggests a temperate climate (MAT: $\sim 7^{\circ} \mathrm{C}$ ). Interestingly, a similar estimate is found if one uses a transfer function proposed by Legendre et al. (2005), developed on the number of cricetid species to infer annual temperatures. The very low number of cricetids in Ulm-Westtangente (2 species) but also in other early Aquitanian localities (e.g. Laugnac, Montaigu-leBlin) also indicates a rather temperate climate (MAT: $\sim 7^{\circ} \mathrm{C}$ ), in contrast to the Middle and Late Miocene situation. An Early Aquitanian low cricetid diversity does not, however, directly imply low MATs, since the evolutionary history of the family has to be taken into account. Glirids were indeed much more abundant back then and only later replaced by cricetids; but it is worth noting that some European Late Oligocene faunas had more cricetid species (see Mennecart et al. 2012, this volume). Additionally, crocodile remains found in Ulm-Westtangente (Heizmann et al. 1989) tend to exclude the existence of a true temperate climate (involving cold winters), and rather coincide with the proximity of some warm-temperate extant faunas in the PCA. Considering that changes of community structures are long-term processes (Montuire and Girard 1998; Maridet et al. 2007), the composition of the UlmWesttangente fauna and the number of cricetid species suggest a temperate-inherited community structure. This implies an ongoing (and progressive) climatic evolution from temperate to subtropical conditions, and Ulm-Westtangente reflecting somehow an intermediate stage in this transition.

The worldwide glaciation event that occurred at the Oligocene-Miocene boundary (Mi-1, Naish et al. 2008; c. 23.03 Ma, Gradstein et al. 2004) is considered as a very short event. It seems that it influenced European terrestrial environments only during the very beginning of the Miocene (Bieterfeld, basal NN1, c. 23 Ma, Mosbrugger et al. 2005). Based on the palaeotemperature estimate, the fauna 
of Ulm-Westtangente (MN2a: c. 21.7-22.6 Ma; Sen 1997) might indicate that the European Aquitanian climate was still relatively cold compared to the late Early Miocene context.

\section{Palaeoecology at Ulm-Westtangente}

The absence of very small-sized carnivores, except maybe Palaeogale sp., is explained by the fact that carnivores often feed on smaller preys, which are easier to catch than bigger preys, especially for solitary hunters (Peigné 2000). Consequently and such as expected and already shown for extant mammal communities (Valverde 1967; Legendre 1988), carnivores are distributed in the intermediate sizes and participate to the gaps in herbivore species in the middle sizes (see cenogram and histograms in Fig. 4). Potential preys probably try to avoid predation through growing bigger or smaller in the course of their evolution (Valverde 1967). Very small preys in extant mammalian communities often are also preyed upon by birds rather than by mammalian predators. Unfortunately, no bird remains were well preserved to be identified with certainty in Ulm-Westtangente (Heizmann et al. 1989). The midsizes gap in herbivores and insectivores shown on the cenogram thus also partly reflects carnivore pressure and is possibly not only the result of environmental conditions (Valverde 1967). The significant but not very strong relationship of gap size to MAP evidenced in Costeur and Legendre (2008a) shows how this gap potentially has several controlling parameters. In addition, the environmental context might be preponderant in explaining the poorly diversified very large size category (over one tonne), while large herbivores are much more diversified in Middle Miocene localities (e.g. 9 species over 1 tonne in Sansan). Indeed, the body mass of the biggest predator of Ulm-Westtangente (Crassidia intermedia; Heizmann and Kordikova 2000) was estimated at less than $200 \mathrm{~kg}$ and was consequently probably too small to be a predator of very large herbivorous mammals such as rhinoceroses. Moreover few megaherbivores are involved in predatorprey relationships (Brown and Maurer 1986), thus falling outside the range of species impacted by the presence of large carnivores. As proposed by Janis et al. (2004) concerning the excess of browsers, and especially large browsers, in mid-Miocene North American faunas, only specific environments unlike extant ones are capable of sustaining such a biomass. The poorly diversified large mammals of Ulm-Westtangente by comparison to middle Miocene localities consequently reflects an environment constrained by a lower primary productivity, possibly linked to lower atmospheric $\mathrm{CO}_{2}$ concentrations (Kürschner et al. 2008). However, the European faunas did not show a high diversity of megaherbivores before the late
Early Miocene. Only at this time did several African megaherbivores enter the continent. The European mammalian evolutionary history thus also explains the low amount of very large herbivores in contrast to other continents like North America or Africa where such animals were already known before the Early Miocene (Janis et al. 1998; Werdelin and Sanders 2010).

\section{Conclusions}

Ulm-Westtangente is the second richest locality known so far in the Aquitanian of Europe after Montaigu-le-Blin. Its fauna comes from a single $35 \mathrm{~cm}$-thick layer and thus is much more constrained than that of Montaigu-le-Blin. The latter possibly records species of the whole Early Aquitanian because of difficulties in assigning old findings to specific outcrops. This makes Ulm-Westtangente one of the most interesting localities to understand the faunal, palaeoecological and palaeoenvironmental context of the European Aquitanian. A cenogram analysis was performed on the whole mammalian fauna together with comparisons with a dataset of extant faunas and an inspection of the ecological requirements of its constituting species. The analyses indicate that the surrounding environments at Ulm-Westtangente were a mosaic of lakes, rivers (e.g. sediments and associated fauna published in Heizmann et al. 1989), and forest and grassland habitats in probably warm-temperate climatic conditions. Close body size spectra are nowadays to be found in temperate forests with grasslands. A tentative palaeotemperature reconstruction points to a temperate climate, which might seem surprising since other reconstructions from different proxies for the Aquitanian rather indicate warm-temperate or subtropical conditions. The limits of the methodologies used here might explain these results; although the overall very Late Oligocene-Early to Middle Miocene climatic context sees an evolution from temperate/warm-temperate to subtropical conditions. Ulm-Westtangente is chronologically in between and could therefore show an intermediate situation. In terms of faunal composition, Ulm-Westtangente has a strong Oligocene inheritance, such as already well known for the Aquitanian of Europe (carnivores, glires and large herbivores). The German fauna shows strong affinities with the French record and less with southeastern regions testifying to significant biogeographic differences. Carnivores, noticeably diversified at Ulm-Westtangente, are mostly distributed around the middle-large sizes of the whole mammalian body mass range. This is a situation known in today's ecosystems. They probably participate in structuring the community, herbivores and insectivores avoiding mid-sizes-hence, size-gaps in this area-to try to avoid predation pressure. Together with environmental 
parameters such as humidity, they thus play an important role in shaping herbivore/insectivore/omnivore mammalian communities.

Acknowledgments This work is dedicated to Burkart Engesser for his outstanding career and all the help and hospitality he provided to visitors of the Natural History Museum Basel, hoping that more is still to come! We are grateful to Damien Becker and Chiara Angelone for fruitful discussions; Reinhard Ziegler (SMNS) allowed access to collections of Ulm-Westtangente in Stuttgart. O.M's research is supported by the Chinese National Natural Science Foundation (Grant No. 41050110135) and a Research Fellowships for International Young Researchers of the Chinese Academy of Sciences (No. 2009Y2BZ3). SP's study of the Carnivores from Ulm-Westtangente was supported by the Alexander von Humboldt Foundation during a postdoctoral research at the SMNS. We further extend our thanks to Damien Becker and Gildas Merceron for their detailed and insightful comments. Marguerite Hugueney is warmly thanked for commenting upon the manuscript.

\section{References}

Aldana-Carrasco, E. J. (1992). Los Sciurinae (Rodentia, Mammalia) del Mioceno de la Cuenca del Vallès-Penedès (Cataluña, España). Treballs del Museu de Geologia de Barcelona, 2, 69-97.

Becker, D. (2003). Paléoécologie et paléoclimats de la Molasse du Jura (Oligo-Miocène): Apport des Rhinocerotoidea (Mammalia) et des minéraux argileux. GeoFocus, 9, 1-327.

Becker, D., Antoine, P.-O., Engesser, B., Hiard, F., Hostetter, B., et al. (2010). Late Aquitanian mammals from Engehalde (Molasse Basin, Canton Bern, Switzerland). Annales de Paléontologie, 96, 95-116.

Becker, D., Picot, L., \& Berger, J.-P. (2002). Diversité et évolution des Rhinocerotoidea : un exemple dans la Molasse du Jura (Suisse). In Troisième symposium international de Paléontologie "Georges Cuvier": de l'Anatomie Comparée à la Paléobiologie", Montbéliard. [Abstract].

Becker, D., Rössner, G. E., Picot, L., \& Berger, J.-P. (2001). Early Miocene ruminants of Wallenried (USM, Aquitanian/Switzerland): Sedimentology, Biostratigraphy and Paleoecology. Eclogae Geologicae Helveticae, 94, 547-564.

Bessedik, M. (1984). The Early Aquitanian and Upper LanghianLower Serravallian environments in the northwestern Mediterranean region. Paléobiologie Continentale, 14, 153-179.

Böhme, M. (2003). The Miocene Climatic Optimum: evidence from ectothermic vertebrates of Central Europe. Palaeogeography, Palaeoclimatology, Palaeoecology, 195, 389-401.

Böhme, M. (2004). Migration history of air-breathing fishes reveals Neogene atmospheric circulation patterns. Geology, 32, 393-396.

Böhme, M., Winklhofer, M., \& Ilg, A. (2011). Miocene precipitation in Europe: temporal trends and spatial gradients. Palaeogeography, Palaeoclimatology, Palaeoecology, 304, 212-218.

Brown, J.H., \& Maurer, B.A. (1986). Body size, ecological dominance and Cope's rule. Nature, 324, 258-250.

Carbone, C., Mace, G. M., Roberts, S. C., \& Macdonald, D. W. (1999). Energetic constraints on the diet of terrestrial carnivores. Nature, 402, 286-288.

Costeur, L. (2005). Cenogram analysis of the Rudabánya mammalian community: palaeoenvironmental interpretations. Palaeontographia Italica, 90, 303-307.
Costeur, L. (2009). Preliminary overview of regional endemism in European Neogene ungulates. Bulletin de la Société Géologique de France, 180, 17-25.

Costeur, L., \& Legendre, S. (2008a). Mammalian communities document a latitudinal environmental gradient during the Miocene Climatic Optimum in Western Europe. Palaios, 23, 280-288.

Costeur, L., \& Legendre, S. (2008b). Spatial and temporal variation in European Neogene large mammals diversity. Palaeogeography, Palaeoclimatology, Palaeoecology, 261, 127-144.

Costeur, L., Legendre, S., \& Escarguel, G. (2004). European large mammals palaeobiogeography and biodiversity during the Neogene. Palaeogeographic and climatic impacts. Revue de Paléobiologie, vol. spéc., 9, 99-109.

Croft, D. A. (2001). Cenozoic environmental change in South America as indicated by mammalian body size distributions (cenograms). Diversity and Distributions, 7, 271-287.

Daams, R., Freudenthal, M., \& van der Meulen, A. J. (1988). Ecostratigraphy of micromammal faunas from the Neogene of Spain. Scripta Geologica, Special Issue, 1, 287-302.

Dallai, L., \& Burgess, R. (2011). A record of Antarctic surface temperature between 25 and 50 m.y. ago. Geology, 39, 423-426.

de Bonis, L., Bouvrain, G., Geraads, D., \& Koufos, G. D. (1992). Diversity and paleoecology of Greek late Miocene mammalian faunas. Palaeogeography, Palaeoclimatology, Palaeoecology, 91, 99-121.

de Bonis, L., Peigné, S., \& Hugueney, M. (1999). Carnivores féloïdes de l'Oligocène supérieur de Coderet-Bransat (Allier, France). Bulletin de la Société géologique de France, 170, 939-949.

Dehm, R. (1950). Die Nagetiere aus dem Mittel-Miocän (Burdigalium) von Wintershof-West bei Eichstätt in Bayern. Neues Jahrbuch für Mineralogie, Geologie und Paläontologie Abhandlungen, B91, 321-428.

Deng, T. (2009). Late Cenozoic environmental changes in the Linxia basin (Gansu, China) as indicated by cenograms of fossil mammals. Vertebrata PalAsiatica, 47, 282-298.

Engesser, B. (1990). Die Eomyidae (Rodentia, Mammalia) der Molasse der Schweiz und Savoyens. Systematik und biostratigraphie. Schweizerische Paläontologische Abhandlungen, 112, $1-144$.

Engesser, B. (1999). Family Eomyidae. In G. E. Rössner \& K. Heissig (Eds.), The Miocene Land Mammals of Europe (pp. 319-335). München: Verlag Dr. Friedrich Pfeil.

Engesser, B., \& Mödden, C. (1997). A new version of the biozonation of the lower freshwater molasse (Oligocene and Agenian) of Swizerland and Savoy on the basis of fossil mammals. In J.-P.Aguilar, S. Legendre \& J. Michaux (Eds.), Actes de Congrès BiochroM'97 (pp. 475-499). Institut de Montpellier, Mémoires et travaux de l'E.P.H.E., 21.

Fritz, H., Duncan, P., Gordon, I. J., \& Illius, A. W. (2002). Megaherbivores influence trophic guild structure in African ungulate communities. Oecologia, 131, 620-625.

Gradstein, F. M., Ogg, J. G., Smith, A. G., Bleeker, W., \& Lourens, L. J. (2004). A new Geologic Time Scale, with special reference to Precambrian and Neogene. Episodes, 27, 83-100.

Hammer, O., Harper, D. A. T., \& Ryan, P. D. (2001). PAST: Paleontological statistics software package for education and data analysis. Palaeontologia Electronica, 4, art. 4, 9 pp.

Heissig, K. (1999). Family Chalicotheriidae. In G. E. Rössner \& K. Heissig (Eds.), The Miocene Land Mammals of Europe (pp. 189-192). München: Verlag Dr. Friedrich Pfeil.

Heizmann, E. P. J. (1998). In Ulm und um Ulm Herum - der Nordrand des Molassebeckens. In E. P. J. Heizmann. (Ed.), Erdgeschichte mitteleuropäische Regionen (2) - Vom Schwarzwald zum Ries (pp. 153-165). München: Verlag Dr. Friedrich Pfeil. 
Heizmann, E. P. J., Bloos, G., Böttcher, R., Werner, J., \& Ziegler, R. (1989). Ulm-Westtangente und Ulm-Uniklinik: Zwei neue Wirbeltier-Faunen aus der Unteren Süsswasswer-Molasse (Untermiozän) von Ulm (Baden-Württemberg). Stuttgarter Beiträge zur Naturkunde Serie B, 153, 1-14.

Heizmann, E.P. J., \& Kordikova, E. G. (2000). Zur systematischen Stellung von «Amphicyon» intermedius H. v. Meyer, 1849 (Carnivora, Amphicyonidae). Carolinea, 58, 69-82.

Heizmann, E. P. J., \& Morlo, M. (1994). Amphictis schlosseri n. sp.eine neue Carnivoren-Art (Mammalia) aus dem Unter-Miozän von Südwestdeutschland. Stuttgarter Beiträge zur Naturkunde Serie B, 216, 1-25.

Hellmund, M. (1991). Schweineartige (Suina, Artiodactyla, Mammalia) aus oligo-miozänen Fundstellen Deutschlands, der Schweiz und Frankreichs. II. Hyotherium meissneri (Suidae) aus dem Untermiozän von Ulm-Westtangente (Baden-Württemberg). Stuttgarter Beiträge zur Naturkunde Serie B, 176, 1-69.

Holling, C. S. (1992). Cross-scale morphology, geometry, and dynamics of ecosystems. Ecological Monographs, 62, 447-502.

Hugueney, M. (1984). Evolution du paléoenvironnement dans le tertiaire de Limagne (Massif Central, France). Geobios, Mémoires Spéciaux, 8, 385-391.

Hugueney, M. (1997). Biochronologie mammalienne dans le Paléogène et le Miocène inférieur du Centre de la France: Synthèse réactualisée. In J.-P. Aguilar, S. Legendre \& J. Michaux (Eds.), Actes de Congrès BiochroM'97 (pp. 417-430). Institut de Montpellier, Mémoires et travaux de l'E.P.H.E., 21.

Hugueney, M. (1999). Genera Eucricetodon and Pseudocricetodon. In G. E. Rössner \& K. Heissig (Eds.), The Miocene land mammals of Europe (pp. 347-358). München: Verlag Dr. Frierich Pfeil.

Hürzeler, J. (1944). Über einen dimyloiden Erinaceiden (Dimylechinus nov gen.) aus dem Aquitanien der Limagne. Ecologae geologicae Helvetiae, 37, 460-467.

Ivanov, D., Utescher, T., Mosbrugger, V., Syabryaj, S., DjordjevićMilutinović, D., \& Molchanoff, S. (2011). Miocene vegetation and climate dynamics in Eastern and Central Paratethys (Southeastern Europe). Palaeogeography, Palaeoclimatology, Palaeoecology, 304, 262-275.

Janis, C. M., Damuth, J., \& Theodor, J. M. (2004). The species richness of Miocene browsers, and implications for habitat type and primary productivity in the North American grassland biome. Palaeogeography, Palaeoclimatology, Palaeoecology, 207, 371-398

Janis, C. M., \& Scott, K. M. (1987). The interrelashionships of higher ruminant families with special emphasis on the members of the Cervoidea. American Museum Novitates, 2893, 1-85.

Janis, C. M., Scott, K. M., \& Jacobs, L. L. (1998). Evolution of Tertiary Mammals of North America. Volume 1: Terrestrial carnivores, ungulates and ungulate-like mammals. Cambridge: Cambridge University Press.

Jiménez-Moreno, G., Fauquette, S., \& Suc, J.-P. (2008). Vegetation, climate and palaeoaltitude reconstructions of the Eastern Alps during the Miocene based on pollen records from Austria, Central Europe. Journal of Biogeography, 35, 1638-1649.

Jiménez-Moreno, G., Fauquette, S., Suc, J.-P., \& Abdul Aziz, H. (2007). Early Miocene repetitive vegetation and climatic changes in the lacustrine deposits of the Rubielos de Mora Basin (Teruel, NE Spain). Palaeogeography, Palaeoclimatology, Palaeoecology, 250, 101-113.

Jiménez-Moreno, G., Rodríguez-Tovara, F. J., Pardo-Igúzquizac, E., Fauquette, S., Suc, J.-P., \& Müller, P. (2005). High-resolution palynological analysis in late early-middle Miocene core from the Pannonian Basin, Hungary: climatic changes, astronomical forcing and eustatic fluctuations in the Central Paratethys. Palaeogeography, Palaeoclimatology, Palaeoecology, 216, 73-97.
Jiménez-Moreno, G., \& Suc, J.-P. (2007). Middle Miocene latitudinal climatic gradient in Western Europe: Evidence from pollen records. Palaeogeography, Palaeoclimatology, Palaeoecology, 253, 208-225.

Kürschner, W. M., Kvaček, Z., \& Dilcher, D. L. (2008). The impact of Miocene atmospheric carbon dioxide fluctuations on climate and the evolution of terrestrial ecosystems. Proceedings of the National Academy of Sciences of the United States of America, 105, 449-453.

Larsson, L. M., Vajda, V., \& Dybkjaer, K. (2010). Vegetation and climate in the latest Oligocene-earliest Miocene in Jylland, Denmark. Review of Palaeobotany and Palynology, 159, 166-176.

Legendre, S. (1986). Analysis of mammalian communities from the late Eocene and Oligocene of Southern France. Palaeovertebrata, 16, 191-212.

Legendre, S. (1988). Contributions à l'étude du gisement miocène supérieur de Montredon (Hérault). Les grands mammifères. 8 Analyse paléoécologique de la faune mammalienne. Palaeovertebrata, Mémoire extraordinaire, 177-186.

Legendre, S. (1989). Les communautés de mammifères du Paléogène (Eocène supérieur et Oligocène) d'Europe occidentale: structures, milieux et évolution. Münchner Geowissenschaftliche Abhandlungen, 16, 1-110.

Legendre, S., Montuire, S., Maridet, O., \& Escarguel, G. (2005). Rodents and climate: A new model for estimating past temperatures. Earth and Planetary Science Letters, 235, 408-420.

Legendre, S., \& Roth, C. (1988). Correlation of carnassial tooth size and body weight in recent carnivores (Mammalia). Historical Biology, 1, 85-98.

Maridet, O., \& Costeur, L. (2010). Diversity trends in Neogene European ungulates and rodents: Large-scale comparisons and perspectives. Naturwissenschaften, 97, 161-172.

Maridet, O., Escarguel, G., Costeur, L., Mein, P., Hugueney, M., \& Legendre, S. (2007). Small mammal (rodents and lagomorphs) European biogeography from the Late Oligocene to the mid Pliocene. Global Ecology and Biogeography, 16, 529-544.

Mein, P. (1999). Biochronologie et phases de dispersion chez les vertébrés cénozoïques. Bulletin de la Société géologique de France, 170, 195-204.

Mein, P., \& Ginsburg, L. (1997). Les mammifères du gisement miocène inférieur de Li Mae Long, Thaïlande: systématique, biostratigraphie et paléoenvironnement. Geodiversitas, 19, 783-844.

Mennecart, B., Scherler, L., Hiard, F., Becker, D., \& Berger, J.-P. (2012). Large mammals from Rickenbach (Switzerland, Reference-Locality MP29, Late Oligocene): Biostratigraphic and paleoenvironmental implications. Swiss Journal of Palaeontology, 131, XX-XX.

Montoya, P., Peñalver, E., Ruiz-Sanchez, F., De Santisteban, C., Alcalá, L., \& Belinchón, M. (1996). Los yacimientos paleontologicos de la cuenca terciaria continental de Rubielos de Mora (Aragón). Revista Española de Paleontología, $n^{\circ}$ extr., 215-224.

Montuire, S., \& Girard, C. (1998). Adaptation to environmental changes: communities need more time than species. Paläontologische Zeitschrift, 72, 241-248.

Montuire, S., Michaux, J., Legendre, S., \& Aguilar, J.-P. (1997). Rodents and climate. 1. A model for estimating past temperatures using arvicolids (Mammalia: Rodentia. Palaeogeography, Palaeoclimatology, Palaeoecology, 128, 187-206.

Morlo, M., \& Peigné, S. (2010). Molecular and morphological evidence for Ailuridae and a review of its genera. In A. Goswami \& A. Friscia (Eds.), Carnivoran Evolution: New views on phylogeny, form, and function (pp. 92-140). Cambridge: Cambridge University Press. 
Mosbrugger, V., Utescher, T., \& Dilcher, D. L. (2005). Cenozoic continental climatic evolution of Central Europe. Proceedings of the National Academy of Sciences of the United States of America, 102, 14964-14969.

Naish, T. R., Wilson, G. S., Dunbar, G. B., \& Barrett, P. J. (2008). Constraining the amplitude of Late Oligocene bathymetric changes in western Ross sea during the orbitally-induced oscillations in the East Antarctic Ice Sheet: 2) Implications for global sea-level changes. Palaeogeography, Palaeoclimatology, Palaeoecology, 260, 66-76.

Nowak, R. M. (1995). Mammals of the World. Baltimore: The Johns Hopkins University Press.

Peigné, S. (1999). Proailurus, l'un des plus anciens Felidae (Carnivora) d'Eurasie: Systématique et évolution. Bulletin de la Société d'Histoire naturelle de Toulouse, 135, 125-134.

Peigné, S. (2000). Systématique et évolution des Feliformia (Mammalia, Carnivora) du Paléogène d'Eurasie. Unpublished Ph.D. thesis, Université de Poitiers, 396 p.

Peigné, S., \& Heizmann, E. P. J. (2003). The Amphicyonidae (Mammalia: Carnivora) from Ulm-Westtangente (MN 2, Early Miocene), Baden-Württemberg, Germany-Systematics and ecomorphology. Stuttgarter Beiträge zur Naturkunde Serie B, 343, $1-133$.

Qiu, Z.-D., \& Ni, X.-J. (2006). Small mammals. In G.-Q. Qi, \& W. Dong (Eds.), Study of Lufengpithecus Hudienensis Locality (pp. 113-131). Beijing Science press.

Rögl, F. (1999). Mediterranean and Paratethys Palaeogeography during the Oligocene and Miocene. Hominoid evolution and climatic change in Europe. Volume 1. In J. Agusti, L. Rook \& P. Andrews (Eds.), The evolution of Neogene terrestrial ecosystem in Europe (pp. 8-22). Cambridge: Cambridge University Press.

Sánchez, I. M., Domingo, M. S., \& Morales, J. (2010). The genus Hispanomeryx (Mammalia, Ruminantia, Moschidae) and its bearing on musk deer phylogeny and systematics. Palaeontology, 53, 1023-1047.

Scherler, L., Becker, D., \& Berger, J.-P. (2011). Tapiridae (Perissodactyla, Mammalia) of the Swiss molasse basin during the Oligocene-Miocene transition. Journal of Vertebrate Paleontology, 31, 479-496.

Sen, S. (1997). Magnetostratigraphie calibration of the European Neogene mammal chronology. Palaeogeography, Palaeoclimatology, Palaeoecology, 133, 181-204.

Stefen, C. (1997). Steneofiber eseri (Castoridae, Mammalia) von des Westtangente bei Ulm im Verglaich zu anderen Biberpopulationen. Stuttgarter Beiträge zur Naturkunde Serie B, 255, 1-73.
Storch, G., Engesser, B., \& Wuttke, M. (1996). Oldest fossil record of gliding in rodents. Nature, 379, 439-441.

Travouillon, K. J., \& Legendre, S. (2009). Using cenograms to investigate gaps in mammalian body mass distributions in Australian mammals. Palaeogeograpghy, Palaeoclimatology, Palaeoecology, 272, 69-84.

Utescher, T., Mosbrugger, V., \& Ashraf, A. R. (2000). Terrestrial climate evolution in northwest Germany over the last 25 million years. Palaios, 15, 430-449.

Valverde, J. A. (1967). Estructura de una communidad de vertebrados terrestres. Monographias de la estacion biologicade Doñana, 1 , $1-129$.

van der Meulen, A. J., \& Daams, R. (1992). Evolution of EarlyMiddle Miocene rodents faunas in relation to long term palaeoenvironmental changes. Palaeogeography, Palaeoclimatology, Palaeoecology, 93, 227-253.

Werdelin, L., \& Sanders, W. J. (2010). Cenozoic Mammals of Africa. Berkeley: University of California Press.

Werner, J. (1994). Beiträge zur Biostratigraphie der Unteren Süßwasser-Molasse Süddeutschlands-Rodentia und Lagomorpha (Mammalia) aus den Fundstellen der Ulmer Gegend. Stuttgarter Beiträge zur Naturkunde Serie B, 200, 1-263.

Zachos, J. C., Pagani, M., Sloan, L., Thomas, E., \& Billups, K. (2001). Trends, rhythms, and aberrations in global climate, 65 ma to present. Science, 292, 686-693.

Ziegler, R. (1989). Heterosoricidae und Soricidae (Insectivora, Mammalia) aus dem Oberoligozän und Untermiozän Süddeutschland. Stuttgarter Beiträge zur Naturkunde Serie B, 154, 1-73.

Ziegler, R. (1990a). Didelphidae, Erinaceidae, Metacodontidae und Dimylidae (Mammalia) aus dem Oberoligozän und Untermiozän Süddeutschlands. Stuttgarter Beiträge zur Naturkunde Serie B, $158,1-99$.

Ziegler, R. (1990b). Talpidae (Insectivora, Mammalia) aus dem Oberoligozän und Untermiozän Süddeutschlands. Stuttgarter Beiträge zur Naturkunde Serie B, 167, 1-59.

Ziegler, R. (1999a). Order Marsupiala. In G. E. Rössner \& K. Heissig (Eds.), The Miocene Land Mammals of Europe (pp. 49-52). München: Verlag Dr. Friedrich Pfeil.

Ziegler, R. (1999b). Order Insectivora. In G. E. Rössner \& K. Heissig (Eds.), The Miocene Land Mammals of Europe (pp. 53-74). München: Verlag Dr. Friedrich Pfeil. 